\title{
The antrum in patients with duodenal and gastric ulcers
}

\author{
J. SCHRAGER, R. SPINK, AND S. MITRA \\ From the Laboratory, Royal Albert Edward Infirmary, Wigan
}

\begin{abstract}
EDITORIAL COMMENT In this histological study of surgical specimens it has been shown that duodenal ulcer is associated with mild inflammation and gastric ulcer with marked changes and degeneration with metaplasia.
\end{abstract}

Very few detailed descriptions of the antrum are available in the literature, yet the importance of this organ has been stressed by many writers in the past (Konjetzny, 1928; Faber, 1935; Hebbel, 1943; Magnus, 1954; Dean and Mason, 1964; and others). An attempt has been made in this laboratory to study the gastric antrum in normal stomachs and in duodenal and gastric ulcer in greater detail.

\section{METHODS}

One hundred and thirty specimens were examined. Seventy-five of these were surgical specimens from cases of duodenal ulcer and 40 from cases of gastric ulcer. Sixteen were from post-mortem specimens removed within a few hours of death, in which as far as could be ascertained, there was no question of gastrointestinal disease. The surgical specimens were opened immediately after operation by cutting along the greater curvature and they were pinned out with care on cork mats. They were formalin fixed immediately. The specimens with duodenal ulcer had a cuff of duodenum some $5 \mathrm{~cm}$. in width. The amount of duodenum in gastric ulcer specimens was much reduced, but all the specimens showed an intact sphincter. The proximal portion of the specimen consisted of gastric mucosa.

After fixation, the specimens were photographed. The size of the photograph was exactly the same as the size of the stomach. A tracing was made from the photograph onto thin paper. The whole of the specimen was cut into longitudinal strips $1-1 \frac{1}{2} \mathrm{~cm}$. broad. Transverse cuts were then made through the strips at three places, the result being 30-40 shorter pieces measuring approximately $6 \mathrm{~cm}$. in length. A plan of these cut strips was made on the tracing from the stomach. The strips were numbered and these numbers entered on the plan. The strips were then processed, blocked in wax, and sectioned on a sledge microtome. The boundary between the antrum and the body mucosa was studied and mapped out and the surface area of the antrum measured with a planimeter. This procedure enabled us to study thoroughly all of the gastric mucosa and get acquainted with the whole of its cellular topography.

The stains used in this study were haematoxylin and eosin and Zimmerman's stain using the method described by Marks and Drysdale (1957); also 30 specimens were stained with Van Gieson stain. The Zimmerman stain was used to show up well the parietal, peptic, and mucous cells. The Van Gieson stain was used to show the increase in fibrous tissue in the mucosa and submucosa.

\section{RESULTS}

CLASSIFICATION OF THE INFLAMMATORY CHANGES The inflammatory changes in the antral mucosa were classified as follows:

1 Changes showing inflammatory reaction and no destruction of pyloric glands, and according to severity, divided into grades A1 and A2 (Figs. 1 and 2); 2 changes resulting in damage and destruction of the pyloric glands with increasing amounts of intestinalization. The final stage showed complete atrophy. According to severity this degree of change was subdivided into B1 (less than $25 \%$ reduction in glands), B2 $(25-50 \%$ reduction in glands), and $\mathrm{B} 3(50-75 \%$ or more reduction in glands), and is shown in Figures 3, 4, and 5.

THE ANTRUM IN DUODENAL ULCER Of the 75 cases of duodenal ulcer, 71 were in males and four were in females.

The duodenal ulcer was situated at the distal boundary of the antrum. In about one-third of the specimens, the ulcer was situated adjacent to the pyloric mucosa, the remainder most often occurring $1 \mathrm{~cm}$. or so distal to the sphincter. The rest of the duodenal mucosa appeared normal. In six cases the ulcer was found to lie across the boundary and to extend into the distal part of the antrum. These cases were mostly those in which the ulcer lay along 


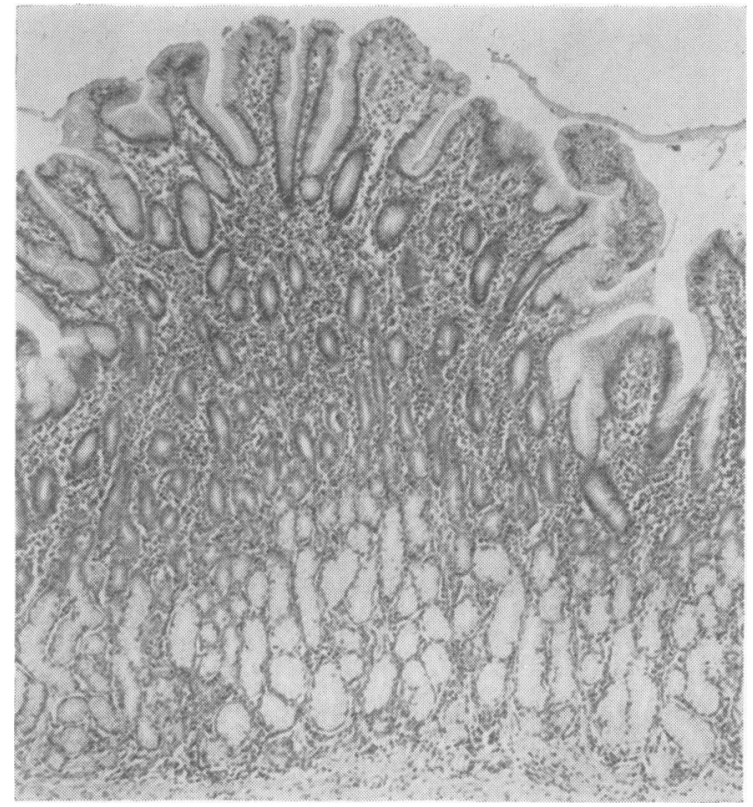

FIG. 1 .

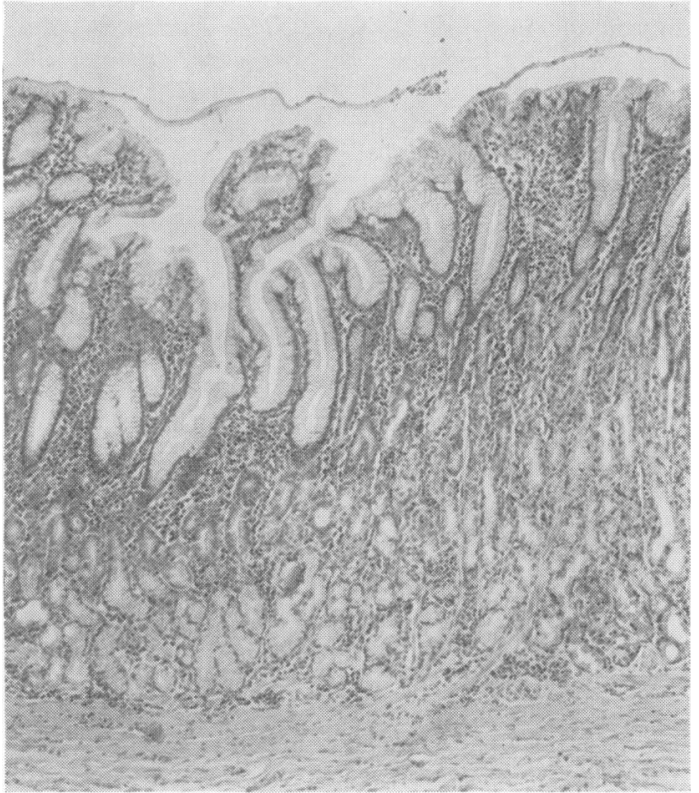

FIG. 2.

FIG. 1. A1. Mild cell infiltration (lymphocyte and plasma cell) but no destruction of pyloric glands.

FIG. 2. A2. Similar changes as found in Fig. 1, but a more severe inflammatory reaction.

FIG. 3. B1. Inflammatory reaction and some destruction of the pyloric glands (less than $25 \%$ reduction in the glands). Two enlarged lymph follicles, one having a germinal centre.

FIG. 4. B2. Similar changes to those found in B1, but a much greater destruction in the pyloric glands.

FIG. 5. B3. Severe inflammatory reaction, with intestinalization, and complete disappearance of pyloric glands.

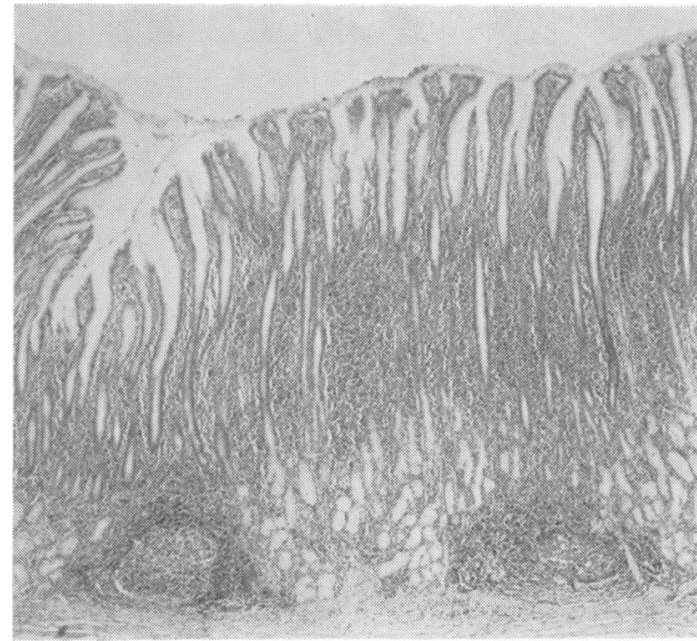

FIG. 3.

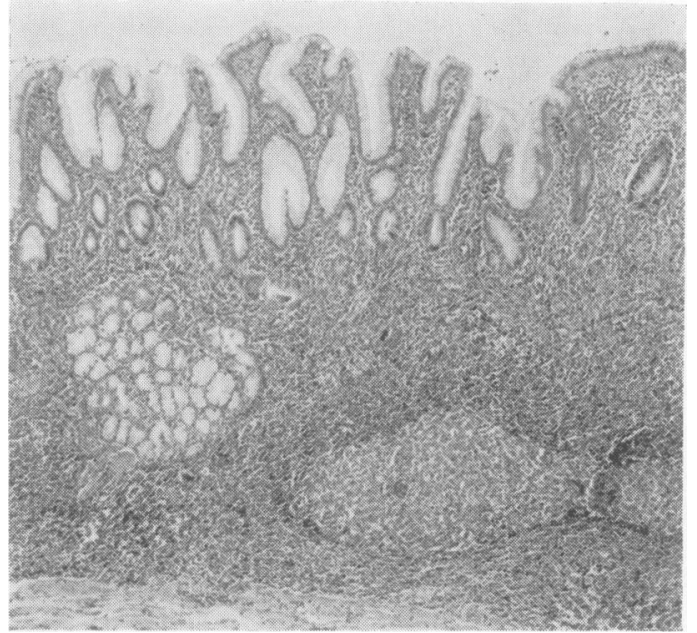

FIG. 4.

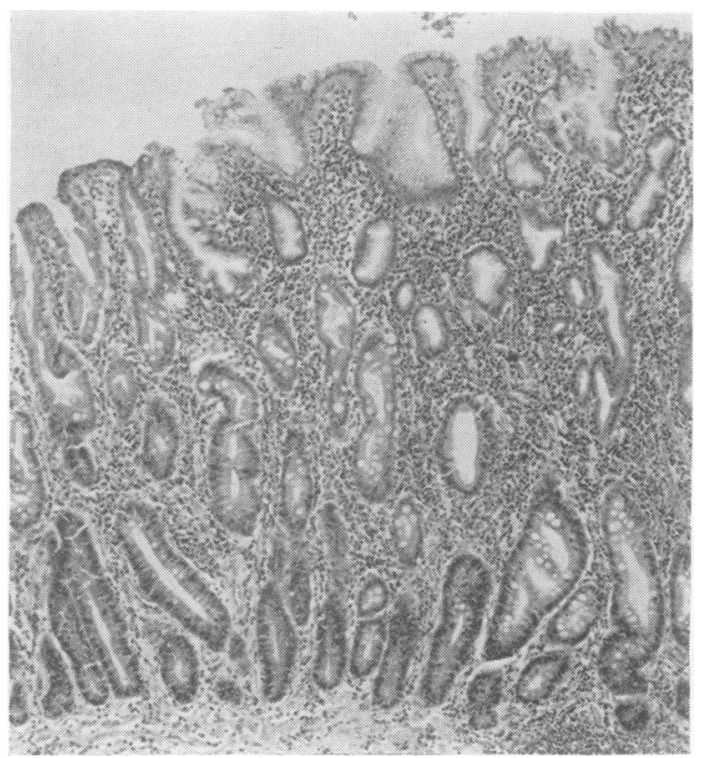

FIG. 5. 
the line of the lesser curvature. In these cases the sphincter had been eroded, and the more superficially situated antral mucosa destroyed.

Table I shows the distribution in 57 specimens. Specimens in which the deformity was so marked as to make the position of the ulcer uncertain were excluded.

TABLE I

SITE OF THE DUODENAL ULCER IN 57 CASES Site of Ulcer

Anterior wall

Posterior wall

Anterior and posterior wall

Single along the line of the lesser curvature

Single along the line of the greater curvature No. of Cases

The inflammatory changes were diffused and involved the whole of the antral mucosa. Most of the cases fell into grade B1 (Table II).

TABLE II

INFLAMMATORY CHANGES ${ }^{1}$

\begin{tabular}{|c|c|c|c|c|}
\hline & \multicolumn{4}{|l|}{ Grade } \\
\hline & $A 2$ & $B I$ & $B 2$ & B3 \\
\hline $\begin{array}{l}\text { Duodenal ulcer } \\
\text { ( } 75 \text { cases) } \\
\text { (average age at } \\
\text { operation } 40\end{array}$ & $\begin{array}{l}15 \\
(17 \%) \\
\text { yr. })\end{array}$ & $\begin{array}{l}46 \\
(64 \%) \\
(3 \text { with shal- } \\
\text { low antral } \\
\text { ulcers) }\end{array}$ & $\begin{array}{l}12 \\
(16 \%) \\
(9 \text { with shal- } \\
\text { low antral } \\
\text { ulcers) }\end{array}$ & $\begin{array}{l}2 \\
(3 \%) \\
(2 \text { with shal- } \\
\text { low antral } \\
\text { ulcers })\end{array}$ \\
\hline $\begin{array}{l}\text { Gastric ulcer } \\
\text { ( } 40 \text { cases) } \\
\text { (average age at } \\
\text { operation } 55\end{array}$ & $\begin{array}{l}- \\
\text { yr.) }\end{array}$ & $\begin{array}{l}10 \\
(25 \%) \\
(7 \text { with } \\
\text { chronic duo- } \\
\text { denal ulcer or } \\
\text { scar) (2 with } \\
\text { shallow antral } \\
\text { ulcers) }\end{array}$ & $\begin{array}{l}19 \\
47 \%) \\
(3 \text { with } \\
\text { chronic duo- } \\
\text { denal ulcer or } \\
\text { scar) (4 with } \\
\text { shallow antral } \\
\text { ulcers) }\end{array}$ & $\begin{array}{l}11 \\
(27 \%) \\
(3 \text { with } \\
\text { chronic duo- } \\
\text { denal ulcer or } \\
\text { scar) (1 with } \\
\text { shallow antral } \\
\text { ulcers) }\end{array}$ \\
\hline
\end{tabular}

The changes were more severe in the mucosa along the lesser curvature near the boundary zone between antrum and body, this part being furthest removed from the region of the ulcer. In the B grades there was found in this area an increasing proportion of stomachs with erosions and shallow ulcers. These diffused inflammatory changes were in very marked contrast with neighbouring body mucosa which appeared entirely normal. The line of transition from inflamed antral to body mucosa was sudden and easily discernible (Fig. 6).

In the more severe grades of inflammation, there was an increase in fibrous tissue in the submucosa.

THE ANTRUM IN GASTRIC ULCER Of the 40 cases of gastric ulcer, 23 were in males and 17 in females.

The most severe inflammatory changes were found in gastric ulcer cases. These showed widespread

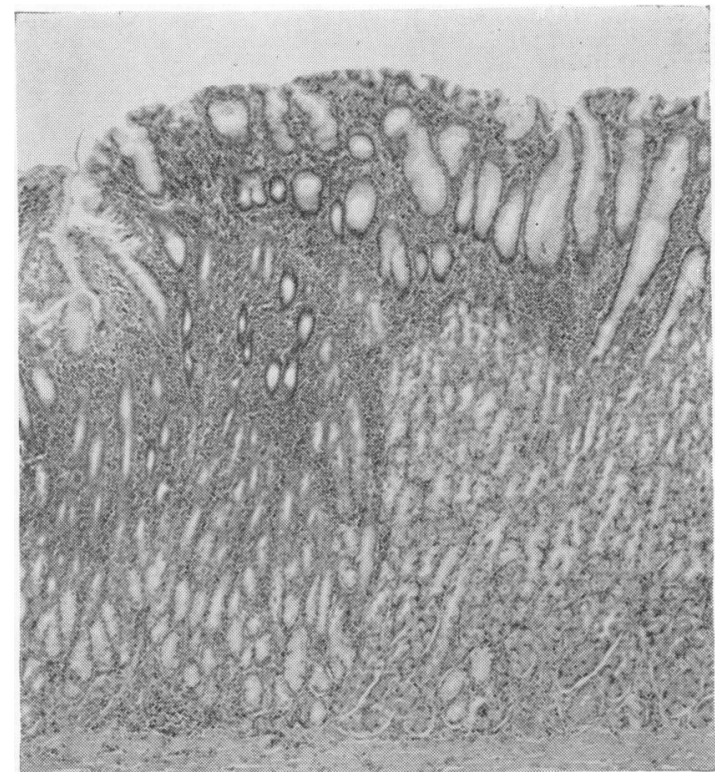

FIG. 6. Sharp boundary zone between antrum and body mucosa. Diffused inflammatory reaction of the antrum stops abruptly at the boundary of normal body mucosa.

destruction of pyloric glands, increasing intestinalization, and in a few cases complete mucosal atrophy. A number were found in grade B1, but as can be seen from Table II, at least three-quarters of the cases occurred in grades B2 and B3. There was also very marked fibrosis in the submucosa. This was marked in areas furthest from the ulcer.

The ulcer itself was situated, as others have noted, near to the proximal boundary of the antrum along the lesser curvature (Magnus, 1954; Minoru Oi, Kingo Oshida, and Sadao Sugimura, 1959). It was found either entirely surrounded by antral mucosa or else partially surrounded by it with the proximal part lying in the boundary zone. It could more justifiably be termed an antral ulcer. It was almost invariably single, only one specimen showing two ulcers, both in this region. The adjoining body mucosa showed a zone of severe gastritis extending for a number of centimetres around it. In a quarter of the cases, the ulceration with its accompanying zone of gastritis had occurred high up the lesser curvature. Although examination could not be as thorough with the ulcer in this situation, there seems little doubt that these ulcers occur at the boundary of body with cardiac mucosa, and that ulceration of this kind is not uncommon.

In seven stomachs the ulceration had been severe enough to have produced stenosis of the pyloric antrum. In spite of the existence of stasis in these 
stomachs, the main inflammatory changes were still to be found in the antrum.

Magnus (1954) has recorded that of 439 cases of chronic gastric ulcer, $54 \%$ of the ulcers occurred over $7.5 \mathrm{~cm}$. from the pylorus in women in comparison with $28 \%$ in men. The record of 40 specimens in this collection is found in Table III.

\section{TABLE III}

DISTANCE BETWEEN LOWER EDGE OF CHRONIC GASTRIC ULCER AND THE PYLORUS

\begin{tabular}{|c|c|c|}
\hline \multirow{2}{*}{ Distance $(\mathrm{cm})}$. & Men & Women \\
\hline & Number & Number \\
\hline $\begin{array}{l}0-2 \cdot 5 \\
2 \cdot 5-5 \cdot 0 \\
5 \cdot 0-7 \cdot 5 \\
7 \cdot 5-10 \cdot 0 \\
10 \cdot 0 \text { and over } \\
\text { Total }\end{array}$ & $\begin{array}{c}1(4 \%) \\
4(17 \%) \\
8(33 \%) \\
8(33 \%) \\
3(12 \%) \\
24\end{array}$ & $\begin{array}{c}3(18 \%) \\
1 \quad(6 \%) \\
5(35 \%) \\
2(11 \%) \\
5(30 \%) \\
16\end{array}$ \\
\hline
\end{tabular}

Although the numbers are small, the preponderance shown is very slight, $45 \%$ occurring over $7.5 \mathrm{~cm}$. in women in comparison with $41 \%$ in men.

It might be remarked here that in this study of the antral mucosa, both in the normal and in cases of disease, apart from the transitional zone at the boundary between pyloric and body mucosa, none of the slides showed the presence of parietal and peptic cells. These were confined entirely to the body mucosa. These findings do not confirm the statement made by some authors, for example, Radasch (1921) and Palmer (1954). that parietal cells are to be found in antral mucosa in small numbers.

There was in the cases of gastric ulcer a rather less abrupt transition from antrum to body mucosa, although in the B1 grade the transition was often as sharp as it was in the duodenal ulcer cases. The remainder of the body mucosa showed a patchy gastritis of variable degree, but there did not appear to be a reduction in parietal and chief cells.

Table II also shows that the gastric ulcer was accompanied in a high proportion of cases by an active duodenal ulcer or ulcer scar. Since the duodenum was not always available for adequate histological examination, it seems likely that had a sufficient amount of duodenum been furnished with all specimens, changes of this kind would have been found in most of them. The figures, although incomplete, nevertheless show a decrease in the proportion of combined ulcer cases with increase in the severity of inflammation. This is likely to be related to the diminution in secretion.

SURFACE AREA OF THE ANTRUM The antra of 45 stomachs obtained at necropsy were investigated.

TABLE IV

$\begin{array}{lll}\begin{array}{l}\text { Case Sex } \\ \text { No. Age } \\ (y r .)\end{array} & \text { Grade } & \begin{array}{l}\text { Measurements along } \\ \text { Lesser Curvature }(\mathrm{cm} .)\end{array} \\ & & \begin{array}{l}\text { Sphincter Width of Sphincter } \\ \text { to Boun- Boundary to Cardia } \\ \text { dary Zone Zone }\end{array}\end{array}$

NORMAL STOMACHS

\begin{tabular}{|c|c|c|c|c|c|}
\hline $\begin{array}{l}\text { Measurements along } \\
\text { Greater Curvature }(\mathrm{cm} .)\end{array}$ & $\begin{array}{l}\text { Distance } \\
\text { between }\end{array}$ & $\begin{array}{l}\text { Distance } T \\
\text { between }\end{array}$ & $\begin{array}{l}\text { Total } \\
\text { Area }\end{array}$ & $\begin{array}{l}\text { Antral } \\
\text { Area }\end{array}$ & Antral \\
\hline $\begin{array}{l}\text { Sphincter Width of Sphincter } \\
\text { to Boun- Boundary to Cardia } \\
\text { dary Zone Zone }\end{array}$ & $\begin{array}{l}\text { and Boun- } \\
\text { dary Zone } \\
\text { as Percen- } \\
\text { tage of } \\
\text { Total Mea- } \\
\text { surement } \\
\text { along Les- } \\
\text { ser Curva- } \\
\text { ture }\end{array}$ & $\begin{array}{l}\text { and Boun- } \\
\text { dary Zone } \\
\text { as Percen- } \\
\text { tage of } \\
\text {-Total Mea- } \\
\text { surement } \\
\text { along } \\
\text { Greater } \\
\text { Curvature }\end{array}$ & a- & & $\begin{array}{l}\text { tage of } \\
\text { Total } \\
\text { Area }\end{array}$ \\
\hline
\end{tabular}

Normals: good histology

\begin{tabular}{|c|c|c|c|c|}
\hline 1 & $\mathbf{M}$ & - & A1 & $9 \cdot 0$ \\
\hline 2 & $\mathbf{M}$ & 76 & A2 & $7 \cdot 0$ \\
\hline 3 & $\mathbf{M}$ & 63 & B1 & 90 \\
\hline 4 & $\mathbf{M}$ & 52 & A2 & $7 \cdot 5$ \\
\hline 5 & $\mathbf{M}$ & 22 & A2 & 8.0 \\
\hline 6 & $\mathbf{F}$ & 73 & B1 & 10.5 \\
\hline 7 & $\mathbf{F}$ & 66 & B2 & $10 \cdot 0$ \\
\hline 8 & $\mathbf{M}$ & 72 & $\mathbf{A 2}$ & $10 \cdot 0$ \\
\hline 9 & $\mathbf{F}$ & 51 & A1 & 8.0 \\
\hline 10 & $\mathbf{M}$ & 66 & B1 & 8.5 \\
\hline 11 & $\mathbf{M}$ & 53 & B2 & $10 \cdot 0$ \\
\hline
\end{tabular}

Normals: indifferent histology

$\begin{array}{lllllll}12 & \text { M } & 62 & - & 9.0 & - & 22 \\ 13 & \text { M } & - & - & 7.0 & - & 22 \\ 14 & \text { M } & - & - & 7.0 & - & 25 \\ 15 & \text { M } & 73 & - & 7.0 & - & 21 \\ 16 & \text { F } & 58 & - & 6.0 & - & 21 \\ 17 & \text { M } & 51 & - & 7.0 & - & 19 \\ 18 & \text { M } & 68 & - & 7.0 & - & 20\end{array}$

$\begin{array}{ll}0 \cdot 8 & 24 \\ 1 \cdot 5 & 24 \\ 0 \cdot 8 & 22 \\ 0 \cdot 8 & 20 \\ 2 \cdot 0 & 20 \\ 0 \cdot 3 & 26 \\ - & 26 \\ 1 \cdot 2 & 23 \\ 0 \cdot 7 & 19 \\ 1 \cdot 0 & 19 \\ - & 25 \\ & \\ - & 22 \\ - & 22 \\ - & 25 \\ - & 21 \\ - & 21 \\ - & 19 \\ - & 20\end{array}$

\section{6}

0.6

0.6

0.4

$0 \cdot 7$

0.5

$\overline{0.6}$

0.5

0.5

$=$
$=$
$=$

\begin{tabular}{l}
40 \\
40 \\
38 \\
36 \\
40 \\
40 \\
42 \\
36 \\
\hline 36 \\
42 \\
\\
42 \\
40 \\
50 \\
38 \\
36 \\
40 \\
36
\end{tabular}

$$
\begin{aligned}
& 40 \\
& 34 \\
& 43 \\
& 40 \\
& 50 \\
& 42 \\
& 38 \\
& 48 \\
& 45 \\
& 50 \\
& 40
\end{aligned}
$$

\begin{tabular}{l}
10 \\
10 \\
11 \\
10 \\
14 \\
15 \\
20 \\
18 \\
\hline 12 \\
10
\end{tabular}

$\begin{array}{lrl}440 & 45 & 10 \\ 420 & 40 & 10 \\ 330 & 40 & 10 \\ 420 & 45 & 10 \\ 350 & 50 & 14 \\ 365 & 55 & 15 \\ 425 & 100 & 23 \\ 415 & 55 & 13 \\ 290 & 55 & 17 \\ 320 & 50 & 15 \\ 600 & 85 & 14\end{array}$

455

355
675

440

325

430

375 
RESECTED STOMACH OF ULCER CASES

\begin{tabular}{|c|c|c|c|c|c|c|c|c|c|c|}
\hline \multirow[t]{2}{*}{$\begin{array}{l}\text { Case } \\
\text { No. }\end{array}$} & \multirow[t]{2}{*}{ Sex } & \multirow[t]{2}{*}{$\begin{array}{l}\text { Age } \\
\text { (yr.) }\end{array}$} & \multirow[t]{2}{*}{ Grade } & $\begin{array}{l}\text { Measurements along } \\
\text { Lesser Curvature }(\mathrm{cm} .)\end{array}$ & $\begin{array}{l}\text { Measurements along } \\
\text { Greater Curvature }(\mathrm{cm} .)\end{array}$ & \multirow{2}{*}{$\begin{array}{l}\text { Distance } \\
\text { between } \\
\text { Sphincter } \\
\text { and Boun- } \\
\text { dary Zone } \\
\text { as Percen- } \\
\text { tage of } \\
\text { Total Mea- } \\
\text { surement } \\
\text { along Les- } \\
\text { ser Curva- } \\
\text { ture }\end{array}$} & \multirow{2}{*}{$\begin{array}{l}\text { Distance } \\
\text { between } \\
\text { Sphincter } \\
\text { and Boun- } \\
\text { dary Zone } \\
\text { as Percen- } \\
\text { tage of } \\
\text {-Total Mea- } \\
\text { surement } \\
\text { along } \\
\text { Greater } \\
\text { Curvature }\end{array}$} & \multirow{2}{*}{$\begin{array}{l}\text { Total } \\
\text { Area } \\
(\mathrm{sq} . \mathrm{cm} .) \\
\text { e } \\
\text { a- } \\
\end{array}$} & \multirow[t]{2}{*}{$\begin{array}{l}\text { Antral } \\
\text { Area } \\
\text { (sq. cm.) }\end{array}$} & \multirow{2}{*}{$\begin{array}{l}\text { Antral } \\
\text { Area as } \\
\text { Percen- } \\
\text { tage of } \\
\text { Total } \\
\text { Area }\end{array}$} \\
\hline & & & & $\begin{array}{l}\text { Sphincter Width of Sphincter } \\
\text { to Boun- Boundary to Cardia } \\
\text { dary Zone Zone }\end{array}$ & $\begin{array}{l}\text { Sphincter Width of Sphincter } \\
\text { to Boun- Boundary to Cardia } \\
\text { dary Zone Zone }\end{array}$ & & & & & \\
\hline
\end{tabular}

\begin{tabular}{|c|c|c|c|c|c|c|c|c|c|c|c|c|c|c|}
\hline \multicolumn{15}{|c|}{ Duodenal Ulcer } \\
\hline 2 & $\mathbf{F}$ & - & B1 & $12 \cdot 0$ & 0.5 & - & $7 \cdot 0$ & 0.5 & - & - & - & 一 & 80 & 一 \\
\hline 3 & $\mathbf{M}$ & 55 & B2 & $5 \cdot 0$ & $1 \cdot 0$ & - & $3 \cdot 0$ & 0.7 & - & - & - & - & 40 & - \\
\hline 4 & $\mathbf{F}$ & 43 & B1 & $6 \cdot 5$ & 0.8 & - & 6.0 & 0.8 & - & - & - & - & 65 & 一 \\
\hline 5 & $\mathbf{M}$ & 44 & B1 & $2 \cdot 5$ & $2 \cdot 5$ & - & $5 \cdot 0$ & $1 \cdot 5$ & - & - & - & - & 35 & - \\
\hline 21 & $\mathbf{M}$ & 27 & B2 & $6 \cdot 5$ & $1 \cdot 0$ & - & $4 \cdot 5$ & $1 \cdot 0$ & - & - & - & - & 50 & - \\
\hline 22 & $\mathbf{M}$ & 40 & B1 & $8 \cdot 0$ & 0.4 & - & 6.0 & 0.4 & - & - & - & - & 70 & - \\
\hline 25 & $\mathbf{F}$ & 40 & B1 & 6.0 & $1 \cdot 2$ & - & 5.0 & 0.7 & - & - & - & - & 50 & - \\
\hline 28 & $\mathbf{M}$ & - & B2 & $5 \cdot 5$ & 0.4 & - & 4.0 & 0.4 & - & - & - & - & 35 & - \\
\hline 29 & $\mathbf{M}$ & - & B2 & 8.0 & $1 \cdot 7$ & - & 7.0 & 0.4 & - & - & - & - & 80 & - \\
\hline 33 & $\mathbf{M}$ & 26 & A2 & 6.5 & 0.6 & - & 4.0 & 0.4 & - & - & - & - & 50 & - \\
\hline 38 & $\mathbf{M}$ & 41 & B2 & 8.0 & 0.5 & - & $7 \cdot 5$ & 0.5 & - & - & - & - & 110 & - \\
\hline 41 & $\mathbf{M}$ & - & B1 & $5 \cdot 5$ & 0.2 & - & 4.0 & 0.3 & - & - & - & - & 45 & - \\
\hline 42 & $\mathbf{M}$ & - & B1 & $9 \cdot 0$ & $1 \cdot 0$ & - & $7 \cdot 0$ & $1 \cdot 0$ & - & - & - & - & 95 & - \\
\hline 46 & $\mathbf{M}$ & 40 & A2 & 8.0 & 0.8 & - & 8.0 & 0.3 & - & - & - & - & 100 & - \\
\hline 49 & $\mathbf{F}$ & - & B1 & $7 \cdot 0$ & 0.6 & - & $4 \cdot 0$ & 0.4 & - & - & - & - & 40 & - \\
\hline 53 & $\mathbf{M}$ & 54 & B1 & 8.0 & 0.6 & - & 8.0 & 0.4 & - & - & - & - & 100 & - \\
\hline 54 & $\mathbf{M}$ & 72 & B1 & $7 \cdot 0$ & $0 \cdot 2$ & - & 6.5 & 0.5 & - & - & - & - & 75 & - \\
\hline 57 & $\mathbf{M}$ & - & B1 & $7 \cdot 0$ & 0.4 & - & $7 \cdot 0$ & $0 \cdot 3$ & - & - & - & - & 75 & - \\
\hline 59 & $\mathbf{M}$ & 64 & A2 & 6.5 & 0.5 & - & 5.0 & 0.4 & - & - & - & - & 55 & - \\
\hline 74 & $\mathbf{M}$ & 48 & B1 & $7 \cdot 0$ & 0.4 & - & 10.0 & 0.6 & - & - & - & - & 110 & - \\
\hline 63 & $\mathbf{M}$ & 34 & A2 & $7 \cdot 5$ & 0.7 & - & 6.5 & 0.7 & - & - & - & - & 75 & - \\
\hline 78 & $\mathbf{M}$ & 43 & B1 & $7 \cdot 0$ & 0.5 & - & $7 \cdot 5$ & 0.6 & - & - & - & - & 100 & - \\
\hline 79 & $\mathbf{M}$ & 32 & B1 & $7 \cdot 0$ & 0.3 & - & 4.0 & 0.4 & - & - & - & - & 65 & - \\
\hline 89 & $\mathbf{M}$ & 72 & A2 & $7 \cdot 0$ & 0.3 & - & 5.0 & 0.5 & - & - & - & - & 60 & - \\
\hline 92 & $\mathbf{M}$ & 45 & B1 & $7 \cdot 0$ & 0.4 & - & 5.0 & $1 \cdot 2$ & - & - & - & - & 70 & - \\
\hline 105 & $\mathbf{M}$ & 47 & B1 & $7 \cdot 5$ & 0.5 & - & $7 \cdot 0$ & 0.4 & - & - & - & - & 70 & - \\
\hline 107 & $\mathbf{M}$ & 38 & B1 & $7 \cdot 5$ & 0.4 & - & 6.0 & 0.7 & - & - & - & - & 65 & - \\
\hline 6 & $\mathbf{M}$ & 54 & B2 & 6.0 & - & - & $5 \cdot 5$ & - & - & - & - & - & 45 & - \\
\hline 10 & $\mathbf{M}$ & 45 & B1 & $8 \cdot 5$ & $1 \cdot 0$ & - & 7.0 & $1 \cdot 0$ & - & - & - & - & 75 & - \\
\hline 11 & $\mathbf{M}$ & 51 & B1 & $6 \cdot 5$ & 0.5 & - & 6.0 & 1.0 & - & - & - & - & 70 & - \\
\hline 14 & $\mathbf{M}$ & 51 & B1 & $7 \cdot 0$ & 0.5 & - & $7 \cdot 0$ & 0.7 & - & - & - & - & 95 & - \\
\hline 15 & $\mathbf{M}$ & - & B1 & $7 \cdot 0$ & - & - & $5 \cdot 5$ & - & - & - & - & - & 70 & - \\
\hline 19 & $\mathbf{M}$ & - & B1 & $7 \cdot 0$ & $1 \cdot 2$ & - & $5 \cdot 5$ & 0.4 & - & - & - & - & 50 & - \\
\hline 17 & $\mathbf{M}$ & 27 & B1 & 6.0 & - & - & 6.0 & - & - & - & - & - & 70 & - \\
\hline 31 & $\mathbf{M}$ & 48 & B2 & $9 \cdot 0$ & 0.7 & - & $5 \cdot 5$ & 0.7 & - & - & - & - & 60 & - \\
\hline 34 & $\mathbf{M}$ & - & B1 & 8.0 & $1 \cdot 0$ & - & 6.0 & $1 \cdot 0$ & - & - & - & - & 65 & - \\
\hline 35 & $\mathbf{M}$ & - & A2 & $5 \cdot 5$ & $1 \cdot 0$ & - & $5 \cdot 5$ & 1.0 & - & - & - & - & 50 & - \\
\hline 37 & $\mathbf{M}$ & 73 & B1 & 6.0 & 0.6 & - & 5.0 & 1.0 & - & - & - & - & 65 & - \\
\hline 47 & $\mathbf{M}$ & 57 & B1 & $7 \cdot 0$ & $1 \cdot 2$ & - & $5 \cdot 5$ & 0.6 & - & - & - & - & 60 & - \\
\hline 50 & $\mathbf{M}$ & 36 & B1 & $9 \cdot 0$ & - & - & 6.0 & - & - & - & - & - & 75 & - \\
\hline 55 & $\mathbf{M}$ & - & B2 & $7 \cdot 0$ & - & - & $7 \cdot 0$ & - & - & - & - & - & 70 & - \\
\hline 58 & $\mathbf{M}$ & 52 & B1 & $9 \cdot 0$ & - & - & 10.0 & - & - & - & - & - & 120 & - \\
\hline 66 & $\mathbf{F}$ & 63 & B1 & $5 \cdot 5$ & $1 \cdot 5$ & - & $5 \cdot 0$ & $1 \cdot 0$ & - & - & - & - & 45 & - \\
\hline 81 & $\mathbf{M}$ & 29 & B1 & $8 \cdot 5$ & - & - & 9.0 & - & - & - & - & - & 90 & - \\
\hline 83 & $\mathbf{M}$ & - & B2 & $7 \cdot 0$ & - & - & $7 \cdot 0$ & - & - & - & - & - & 95 & - \\
\hline 92 & $\mathbf{M}$ & 45 & B1 & $7 \cdot 0$ & 0.5 & - & 6.0 & $1 \cdot 2$ & - & - & - & - & 70 & - \\
\hline 102 & $\mathbf{M}$ & 25 & B1 & 8.0 & - & - & $5 \cdot 0$ & - & - & - & - & - & 65 & - \\
\hline 118 & $\mathbf{M}$ & 53 & B2 & $8 \cdot 0$ & - & - & 6.0 & - & - & - & - & - & 70 & - \\
\hline 39 & $\mathbf{M}$ & - & B3 & $5 \cdot 5$ & 0.5 & - & 3.0 & 0.3 & - & - & - & - & 40 & - \\
\hline 111 & $\mathbf{M}$ & 35 & B1 & $6 \cdot 5$ & - & - & $4 \cdot 5$ & - & - & - & - & - & 55 & - \\
\hline 24 & $\mathbf{M}$ & - & B1 & 6.0 & - & - & 6.0 & - & - & - & - & - & 70 & - \\
\hline 48 & $\mathbf{M}$ & - & B1 & $9 \cdot 0$ & - & - & $7 \cdot 0$ & - & - & - & - & - & 90 & - \\
\hline 30 & $\mathbf{M}$ & - & B1 & $9 \cdot 0$ & - & - & 5.0 & - & - & - & - & - & 90 & - \\
\hline
\end{tabular}

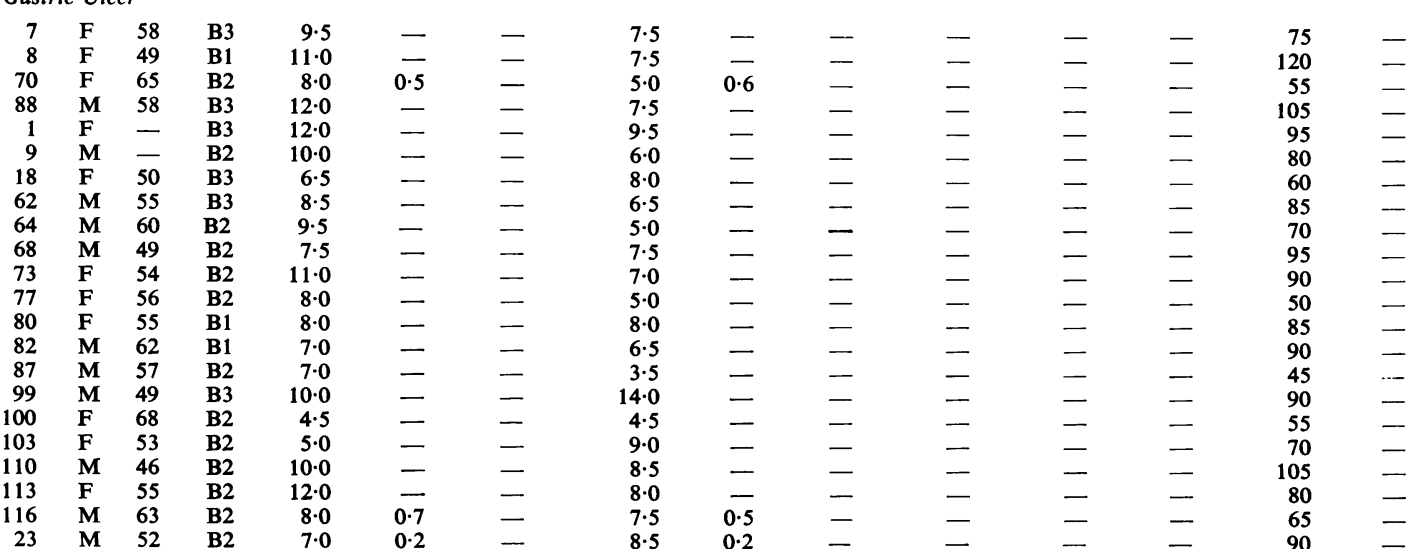


TABLE VI

STOMACHS OF ULCER CASES STUDIED AT NECROPSY

\begin{abstract}
Case Sex Age Grade Measurements along
No. $\quad(y r$.

Lesser Curvature $(\mathrm{cm}$.

Sphincter Width of Sphincter to Boun- Boundary to Cardia dary Zone Zone
\end{abstract}

\begin{tabular}{l}
$\begin{array}{l}\text { Measurements along } \\
\text { Greater Curvature }(\mathrm{cm} .)\end{array}$ \\
\hline $\begin{array}{l}\text { Sphincter Width of Sphincter } \\
\text { to Boun- Boundary to Cardia } \\
\text { dary Zone Zone }\end{array}$
\end{tabular}
dary Zone Zone

\begin{tabular}{|c|c|c|c|c|}
\hline $\begin{array}{l}\text { Distance } \\
\text { between } \\
\text { Sphincter } \\
\text { and Boun- } \\
\text { dary Zone } \\
\text { as Percen- } \\
\text { tage of } \\
\text { Total Mea- } \\
\text { surement } \\
\text { along Les- } \\
\text { ser Curva- } \\
\text { ture }\end{array}$ & $\begin{array}{l}\text { Distance } \\
\text { between } \\
\text { Sphincter } \\
\text { and Boun- } \\
\text { dary Zone } \\
\text { as Percen } \\
\text { tage of } \\
\text {-TotalMea- } \\
\text { surement } \\
\text { along } \\
\text { Greater } \\
\text { Curvature }\end{array}$ & $\begin{array}{l}\text { Total } \\
\text { Area } \\
(\mathrm{sq} . \mathrm{cm} .) \\
\\
e \\
e\end{array}$ & $\begin{array}{l}\text { Antral } \\
\text { Area } \\
\text { (sq. cm.) }\end{array}$ & $\begin{array}{l}\text { Antral } \\
\text { Area as } \\
\text { Percen- } \\
\text { tage of } \\
\text { Total } \\
\text { Area }\end{array}$ \\
\hline
\end{tabular}

$\begin{array}{ll}= & = \\ = & = \\ = & = \\ = & =\end{array}$

As far as one could ascertain there was no history of gastrointestinal disease. The normal stomachs showing reasonably clear histology were not easily obtained due to the speed with which autolysis occurs after death. Only 13 stomachs showed reasonably good histology, and the surface area of the antra of these was accurately charted and the boundary with the body mucosa was established. The area of the antrum in the controls is compared with the area found in cases of duodenal and gastric ulceration in Fig. 7 and Fig. 8 compares the total area of the stomach in the normals with the total area found incidentally in 18 cases of ulcer at necropsy. The mean differences in Fig. 8 were slight.

If the average for the normal antral area is put at $50 \mathrm{sq}$. cm., about two-thirds of the duodenal ulcer cases show areas larger than this. In gastric ulcer cases the area is shown to be greater still and almost invariably twice the size of the normal controls. These measurements suggest that the antrum in ulcer cases is larger than in normal cases. This dirîerence in antral size is shown also by lesser and greater curvature measurements.

The normal stomachs showing reasonably good histology provide the most complete information (Table IV). The measurements include the distance between the sphincter and boundary zone along the lesser and greater curvatures, and the distance between sphincter and cardia along the lesser and greater curvatures.

The sphincter boundary zone distance expressed as a percentage of the total sphincter-cardia distance along the lesser curvature is a little over $40 \%$, and the same percentage along the greater curvature is usually a little over $10 \%$. These figures correspond to those given by Landboe-Christiensen (1944).

It was not found possible to obtain complete measurements in resected stomachs, but the sphincter-boundary zone distance along the lesser and greater curvatures could be measured in suitable cases. These could be compared with the sphinctercardia distances found in eight post-mortem stomachs showing ulcers which were found suitable for measurement. These show that the sphincterboundary zone distances expressed as a percentage of the total sphincter-cardia distance along the lesser curvature gives about the same figure as in the normals, whereas the figure for the greater curvature is in the region of $18 \%$ (Tables $\mathrm{V}$ and $\mathrm{VI}$ ).

From Table $\mathrm{V}$ it will be seen that the sphincterboundary zone distances in ulcer cases along the lesser curvature show considerable variation from 5 to $12 \mathrm{~cm}$. The ulcer was found in most cases at the boundary, and it is apparent that it may vary considerably from the position of the incisura wherever that may be placed. The sphincter-boundary zone distance along the greater curvature also showed considerable variation, but in no case in either ulcer or normal stomachs was the boundary zone found at the pyloric sphincter but always several centimetres proximal to it.

The general outline of the antral mucosa in the normal was a saddle shape, and in the ulcer cases it was larger and more roughly cylindrical, the latter shape the one depicted in some anatomical textbooks, e.g., Gray, Morris, Cunningham.

Included in Table $\mathrm{V}$ are measurements which were made where feasible of the width of the boundary zone. This showed considerable variation as might be expected, for since there was marked inflammation present in most, it was difficult to be certain if the pyloric glands in conjunction with gastric (body) glands had not arisen as a process of pylorisation. In some cases the width was very narrow. The mean 

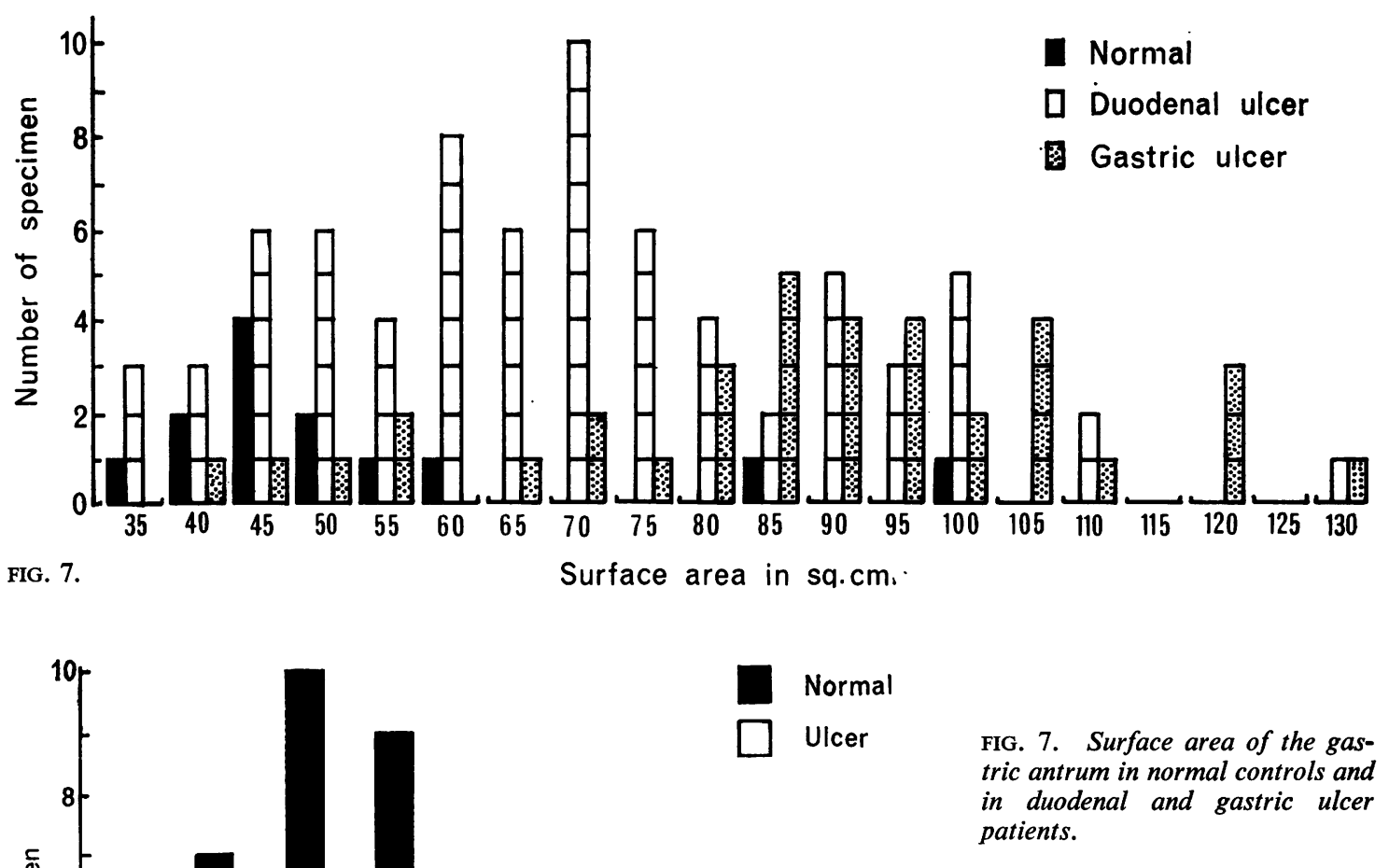

FIG. 8. Total area from postmortem stomach in normal and ulcer cases.

FIG. 8.

was little different on lesser and greater curvatures and measured approximately $0.4 \mathrm{~cm}$. This is a little greater than that found by Oi and others $(0 \cdot 3 \mathrm{~cm}$.). The width did not differ materially between normal and ulcer stomachs, and the figures were too small to affect the sphincter-boundary distances.

It will be seen from Table IV that in the normal stomachs the proportion of the antral area in comparison with the area of the whole of the stomach mucosa was found to vary from 10 to $15 \%$. This corresponds to the average of $12 \%$ given by Landboe-Christiensen (1944). Unfortunately, it was not found possible to obtain corresponding figures for ulcer cases. If the mean size of the ulcer stomach is taken to be 500 sq. cm., about one-fifth of the ulcer stomachs would show an area greater than $20 \%$.

The increase in area was found in both sexes, and no significant difference in variation in size in gastric and duodenal ulceration could be found between them.

It would also appear that the increase in area is associated with an increase in severity of inflammation. This is found in grades A2 and B1 (Fig. 9) in the cases showing mainly duodenal ulceration and is more obviously shown in grades B2 and B3 


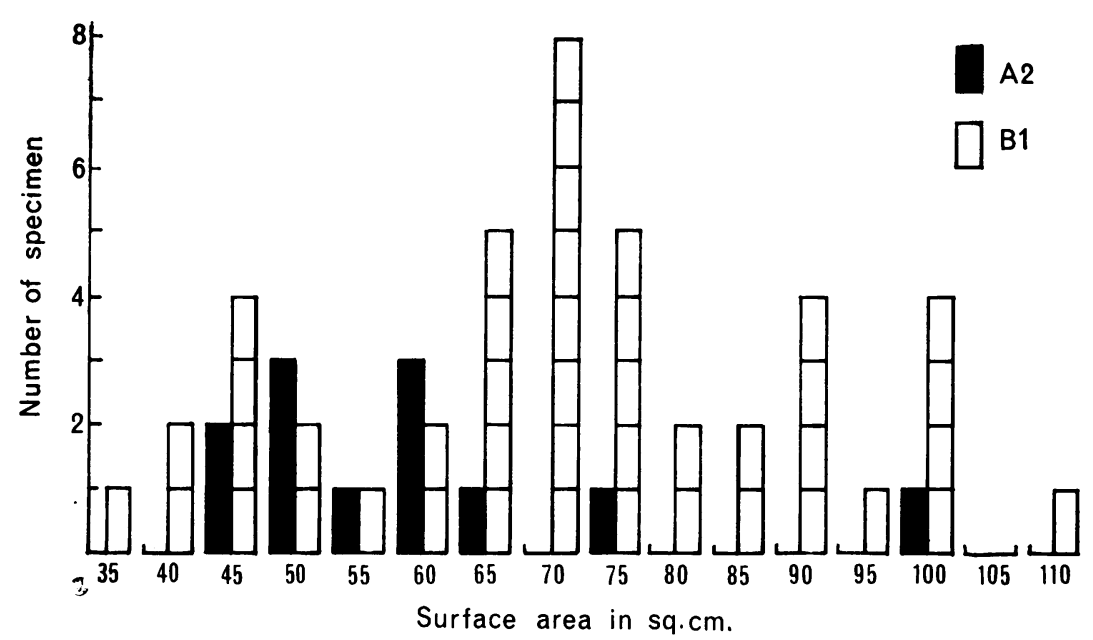

FIG. 9. Relation between antral area and grade of gastritis in duodenal ulcer.

which are cases showing mainly antral ulceration (Fig. 7).

EFFECT OF MUCOSAL DAMAGE ON SECRETION A number of the cases studied were found to have had secretory investigations performed on one (and sometimes more than one) occasion before operation. It was therefore possible to relate the basal secretion to the histological grading. The results are shown in Table VII.

\section{TABLE VII}

BASAL SECRETION RELATED TO HISTOLOGICAL GRADING

\begin{tabular}{|c|c|c|c|c|c|c|c|c|}
\hline \multirow[t]{2}{*}{ Type of Secretor } & \multicolumn{4}{|c|}{$\begin{array}{l}\text { Duodenal Ulcer } \\
\text { (55 Cases) }\end{array}$} & \multicolumn{4}{|c|}{$\begin{array}{l}\text { Gastric Ulcer } \\
\text { (30 Cases) }\end{array}$} \\
\hline & $A 2$ & $B 1$ & $B 2$ & $B 3$ & $A 2$ & $B I$ & $B 2$ & $B 3$ \\
\hline $\begin{array}{l}\text { Hypersecretor } \\
\text { Normosecretor } \\
\text { Hyposecretor }\end{array}$ & $\begin{array}{l}5 \\
4 \\
0\end{array}$ & $\begin{array}{r}21 \\
10 \\
4\end{array}$ & $\begin{array}{l}1 \\
1 \\
7\end{array}$ & $\begin{array}{l}0 \\
1 \\
1\end{array}$ & $\begin{array}{l}0 \\
0 \\
0\end{array}$ & $\begin{array}{l}2 \\
4 \\
0\end{array}$ & $\begin{array}{r}1 \\
5 \\
11\end{array}$ & $\begin{array}{l}0 \\
0 \\
7\end{array}$ \\
\hline
\end{tabular}

Most of the cases in grades A2 and B1 showed hypersecretion. Grades B2 and B3 included cases which showed mostly a marked hyposecretion. The cases with reduced secretion showed a substantial reduction in the number of pyloric glands. This diminished the basal secretion of free acid to a low level, and in most cases it was zero

On referring to Table II, it is seen that most of the combined ulcers occur in the B1 grade, which is the grade to show the highest number of hypersecretors.

\section{DISCUSSION}

The term gastritis, when used to describe inflammatory changes in cases of duodenal and gastric ulcer, suggests that the changes are to be found throughout the organ. Workers in this field, who had access to fresh surgical specimens, maintain that the inflammatory changes are confined to the antrum. The term antritis would be a better one in describing the essential pathology of duodenal and gastric ulcer.

Faber (1927-35) found the changes to be confined to the antrum, and his material included resected specimens in which a gastroenterostomy had been performed previously. In these cases the changes were confined to the antrum and did not involve the body where the gastroenterostomy opening lay. Konjetzny (1928), writing at the same period, described the changes as being confined to the antrum and quotes other German authors (Puhl, Orator) in support.

Magnus and Rodgers (1938), of 92 cases of gastric ulcer and found the changes confined to the antrum in $70 \%$ and in 20 cases of duodenal ulcer the inflammation was invariably in the antrum. Hebbel (1943) did not find the inflammatory changes in the body in cases of duodenal ulcer, and in gastric ulcer it was confined to the region of the ulcer. Obstruction did not result in damage to the body mucosa. Meyers (1948), examining material from 25 cases of duodenal ulcer and 25 of gastric ulcer obtained at operation, found the inflammation to be confined to the antrum, and Magnus (1952) based similar conclusions on the examination of 635 partial gastrectomy specimens. Of 284 specimens of active gastric ulcer, in $76 \%$ of the cases the inflammation was confined to the antrum and in 256 cases of duodenal ulcer it was confined to the antrum in $100 \%$. Thompson (1959) found inflammatory changes to be confined to the antrum and boundary zone.

All authors have found the inflammatory changes to be more intense in cases of gastric ulcer. The amount of metaplasia in cases of gastric ulcer is 
much increased, and is not so often found in duodenal ulcer. The maximum changes occur in the region of the lesser curvature.

Having localized the changes to the antrum, most authors have held the view that the inflammatory changes have preceded the ulceration, and that the inflammation of the antrum is the more fundamental change, upon which the ulceration has been superimposed. This view was certainly taken by pathologists who based their conclusions on examination of post-mortem material before surgical specimens became available in large amounts. Stewart (1922-23), as the result of painstaking examination of 1,500 stomachs at necropsy and 120 operation specimens, expressed the view that the ulcer was preceded by microscopic erosions and macroscopically visible shallow (subacute) ulcers both in the duodenum and antrum. Most of these would heal, but other factors, not necessarily those producing the erosions, would result in a chronically inflamed ulcer. This, although often multiple in the duodenum, was usually single in the stomach. The chronic ulcers tended always to heal in time, and gastric ulcer scars were commonly found in this material. He noted that healing only infrequently produced stenosis.

Faber (1927) and Konjetzny (1928) described all stages in the evolution of the chronic ulcer from numerous small inflammatory erosions and held the view that the inflammatory changes preceded the ulceration. Faber also discussed the experience of surgeons who had furnished him with cases in which there had been a diagnosis of duodenal ulcer on radiological evidence with marked hyperchlorhydria. At operation no ulcer was found, but a severe antral inflammation with multiple erosions. These cases do not occur with great frequency, and individual cases have been written up and are found scattered throughout the literature (for example, Papayannopoulos, Dedes, Kasralis, and Arealis, 1957; Gilmour, 1961). Faber noted that erosions did not occur with great frequency and this may be the result of most of the stomachs removed at operation being in a more or less quiescent stage. Magnus found (1946) a similar state of affairs on examining 20 normal stomachs at necropsy and 100 partial gastrectomy specimens. The antral mucosa showed all stages from microscopic erosions to complete intestinalization. The intestinalization was characteristic more of the gastric than the duodenal ulcer. He pointed out that erosions were not as frequently found as one might expect; he found it in $4 \%$ of his cases. Magnus (1952), on the basis of an examination of 284 specimens with active gastric ulcer, found it in $7 \%$. Thompson (1959) examined 35 cases of gastric ulcer, 54 of duodenal ulcer, and 12 of combined ulcer. He found all grades of inflammatory change from multiple microscopic erosions to extensive metaplasia as a final result. Erosions occurred roughly in $17 \%$ of his cases. This is about the same as has been found in this collection.

Hebbel (1943) examined 78 cases of duodenal ulcer, 16 of gastric ulcer, and 13 of combined ulcer. He concluded that ulceration developed on the basis of a degenerated mucosa. His system of grading showed the mucosa in cases of gastric ulcer to be severely affected in most cases in contrast to cases of duodenal ulcer. He found erosions in only three cases.

The gastric ulcer was described by Stewart (1923 a and b) as lying almost invariably along the lesser curvature near to or at the incisura (Hurst and Stewart, 1929). More recently authors who have made a detailed study of the histology of the antral mucosa describe the gastric ulcer as being invariably situated in the antrum. Magnus (1954), in an analysis of 421 cases of gastric ulcer, comes to the same conclusion. This point was also made by Oi et al. (1959) who examined 149 cases of gastric ulcer. The same conclusion was reached by Dean and Mason (1964) as the result of examining 117 partial gastrectomy specimens. Du Plessis (1963), however, found on examining 41 cases that $70 \%$ occurred in the antrum and $29 \%$ in the fundic mucosa. He attributes the findings of other authors to the pylorization accompanying the development of a gastric ulcer in the body mucosa, which would make it appear that the ulcer lay in the pyloric gland area, whereas in reality it lies in a more proximal position.

It has been tacitly assumed in the past that although it is likely that the gastric ulcer develops on the basis of an inflammatory degeneration of the mucosa, the duodenal ulcer is a different manifestation of the disease, and it is only by chance that the two are occasionally found to coexist (Tanner, 1954; Johnson, 1955). However, authors who have collected statistics for combined ulcers are usually of the opinion that the number of coexistent ulcers in any numerous set of gastric and duodenal ulcers is too large to be the result of chance. Weisberg and Glass (1963) in their review of this topic have included figures from radiological, surgical, and post-mortem studies by a dozen authors. The post-mortem figures collected over many years are particularly impressive (Watkinson, 1960). The figures for combined ulcers in gastric ulcer cases show a considerably high percentage ranging from 30 to 40 , whereas, as might be expected, those from cases of duodenal ulcer are very variable and considerably lower. It is pointed out by many authors interested in this aspect, perhaps because most of them are surgeons, that it is not an uncom- 
mon experience for a surgeon on clinical and other evidence to regard the case as one of duodenal ulcer, and at operation several years later to find an active gastric ulcer with evidence of duodenal scarring. This makes it likely that in many, if not most cases of ulcer, a duodenal ulcer develops first and a gastric ulcer develops later after the duodenal ulcer has healed. Unfortunately this leaves unanswered why only a small number of patients in comparison with the total develop a gastric ulcer. The healing of the duodenal ulcer has been ascribed to the decrease in secretion in the later stages of the disease.

The results of this investigation substantiate most of the findings of previous investigators that the main inflammatory changes were to be found in the antrum. These changes were of varying degrees of severity from the relatively mild changes in cases of duodenal ulcer to the severe degeneration and diffused metaplasia found in most cases of gastric ulcer. The changes, although involving the whole of the antral mucosa, stopped abruptly at the proximal border. The widespread involvement did not appear to be secondary to the ulcer. It is just as intense in cases where there is a healed scar only as in cases with a large active ulcer. The inflammatory reaction was more pronounced at the proximal border than in the proximity of the ulcer. These findings suggest that the inflammatory reactions are a primary manifestation and that the ulcer is a sequence to these more profound changes.

The pathology of the surgical specimens fell into two groups:

1 INFLAMMATORY CHANGES Lymphocyte and plasma cell infiltration involving in varying degree the whole depth of the mucosa, but the pyloric glands remaining intact: these changes were associated with excess secretion of acid and pepsin and the development of duodenal ulcer.

2 EPITHELIAL CHANGES Increase in connective tissue, degeneration of the pyloric glands and metaplasia: these changes present a broad spectrum, namely, progressive degeneration of the pyloric glands, patchy metaplasia; complete disappearance of the pyloric glands and complete intestinalization and thinning of the mucosa with fibrosis of the submucosa. These changes were usually associated with hyposecretion of acid and pepsin and gastric ulcer. Cases with complete achlorhydria usually show an antrum with complete metaplasia.

There is both in the duodenal and gastric ulcers a wide range of histological appearances of the antral mucosa, corresponding to those given in the classical accounts, with a high proportion of cases showing concomitant ulceration. This strongly suggests that the two groups correspond to an early and late stage of what is essentially one continuous pathological process, proceeding with increasing severity over the years. The body mucosa appears to have a high degree of resistance, it appears normal in cases of duodenal ulcer, and shows only patchy superficial inflammatory reaction in cases of gastric ulcer. There is no apparent decrease in its parietal and peptic cell population. The area showing the weakest resistance appears to be the zones forming the boundary between the two cellular populations. Three such zones are to be found: (1) the boundary between the cardiac glands and the body mucosa; (2) the boundary between body mucosa and antrum; and (3) the boundary between antrum and duodenum.

The early changes consist of the development of inflammation and ulceration of the duodenal mucosa adjacent to the sphincter. The severity of the disease may not for many reasons be so severe that antral resistance is completely broken down, but in some cases there is deterioration to a point beyond which no repair is possible and metaplasia occurs. Chronic ulceration will occur at a site nearest the acidsecreting body mucosa.

As a result the inflammatory changes are not found in the duodenum as a whole and stop abruptly at the proximal boundary of the antrum, and the chronic ulceration when found is always at the distal margin of the proximal and distal boundaries. These findings lend strong support to the idea that the acid secretion from the body mucosa is a major factor in the production of the inflammatory changes.

It is possible that the factor of stasis plays a part, but this is difficult to assess. It may be significant that when organic obstruction is present, the inflammatory changes are most marked distal to the obstruction, which would suggest that the factor is not of great consequence.

It seems likely that the hyposecretion found in the later stages of the disease results more from degeneration of the antral mucosa than injury to the body mucosa (for an opposing view see Marks and Shay, 1959). Although degenerative changes are found in the region of the ulcer, the body mucosa appears to be intact when sufficient of the specimen is present for adequate histological examination. In the material examined here the body mucosa in gastric ulcer cases did not differ in structure from the mucosa in duodenal ulcer cases, and except for a gastritis of patchy and variable character, there was little difference from the normal. It was also of interest to note that in the cases in which a full fractional gastric analysis had been done, it was unusual for there to be no response to ordinary 
doses of histamine, and it seems likely that in doubtful cases a more marked response might have been forthcoming had the dose of histamine been increased. In fact in most cases the response was marked. This corresponds to the results of other authors who have investigated the hypochlorhydria following gastric ulcer (James and Pickering, 1949; Watkinson and James, 1951). It indicates that most of the body glands are still functioning. The degeneration of the antral mucosa must produce a decrease in its endocrine activity and in the late stages all activity would be destroyed. Also the submucosal fibrosis may well interfere with innervation. It seems unlikely that abnormal production of hormone is responsible for the development of a gastric ulcer (for an opposing view see Dragstedt et al., 1954).

The measurement of the total extent of the gastric mucosa in stomachs with and without ulceration shows that the rather larger size of the stomachs with ulcer is the result of increased size of the antrum, which is present in both duodenal and gastric ulcer cases but is more marked in gastric ulcer. Although some cases of gastric ulcer show extensive pylorization of the body mucosa near to the boundary, this does not prevent the boundary from being mapped out with reasonable accuracy. The enlarged antrum in these cases may explain the leaving behind of appreciable amounts of antrum after partial gastrectomy in some cases. It is of interest to consider that from the earliest days of gastric surgery, a less radical operation commonly practised for the treatment of gastric ulcer would be unsuitable for the treatment of a duodenal ulcer. This is very likely due to the marked changes found in the antral mucosa in cases of gastric ulcer, that is, degeneration of pyloric glands, metaplasia, and atrophy. It is reasonable to assume that these changes have affected the secretory activity of the antrum, reducing or destroying it. The unsuccessful results in duodenal ulcer cases are due to the leaving behind of a more or less intact antral mucosa with the persistence of hypersecretion, and tendency to recurrent ulceration. A patient with a partial gastrectomy and recurrent ulceration often shows that some antral mucosa has been left behind(Dean and Mason, 1964).

It seems from the findings here that increased size is in some way connected with more severe grades of degeneration of the antral mucosa and eventual hyposecretion. Before more concrete suggestions can be made as to the significance of these anatomical findings, much more will have to be known about the physiology of gastric secretion in man.

\section{SUMMARY}

Seventy-five surgical specimens of duodenal ulcer and 40 of gastric ulcer were sectioned and graded according to the severity of the inflammatory changes in the antral mucosa. The main changes were found only in the antrum, and were primary and independent of the ulcer. Duodenal ulceration was associated with mild inflammation, and gastric ulceration with marked changes and degeneration with metaplasia. The degeneration was accompanied by diminution in gastric secretion. The size of the antrum in cases of ulcer was found to be increased when compared with that in 16 normal stomachs. The possible significance of this finding is discussed.

We are indebted to the late Professor H. A. Magnus for reading the manuscript and for his valuable advice and criticism. The late Mr. Ian Orr, F.R.C.S., Royal Infirmary, Preston, provided most of the surgical specimens. We wish to thank Mr. Ramsden, of the Royal Infirmary, Preston, and Mr. Molyneux, of the Royal Infirmary, Leigh, who provided the photographs, and Mrs. P. Rimmer for the arduous job of section cutting, Dr. Woodcock of the General Infirmary, Bolton, who provided many of the post-mortem specimens, together with other members of the Wigan Infirmary staff. This investigation was supported by a financial grant from the Regional Hospital Board, Manchester.

\section{REFERENCES}

Dean, A. C. B., and Mason, M. K. (1964). The distribution of pyloric mucosa in partial gastrectomy specimens. Gut, 5, 64-67.

Dragstedt, L. R., Oberhelman, H. A. Jnr., Evans, S. O., and Rigler, S. P. (1954). Antrum hyperfunction and gastric ulcer. Ann. Surg., 140, 396-404.

Du Plessis, D. J. (1960). Some aspects of the pathogenesis and surgical management of peptic ulcers. S. Afr. med. J., 34, 101-108.

(1963). The importance of the pyloric antrum in peptic ulceration. S. Afr. J. Surg., $1,3$.

(1965). Pathogenesis of gastric ulceration. Lancet, 1, 974-978.

Faber, K. (1927). Schorstein lecture on chronic gastritis: its relation to achylia and ulcer. Ibid., 2, 901-907.

--, (1935). Gastritis and its Consequences. Oxford University Press, London.

Gilmour, J. (1961). The surgical aspects of gastritis and its role in gastric pathology. Brit. J. Surg., 49, 278-288.

Hebbel, R. (1943). Chronic gastritis: its relation to gastric and duodenal ulcer and to gastric carcinoma. Amer. J. Path., 19, 43-71.

Hurst, A. F., and Stewart, M. J. (1929). Gastric and Duodenal Ulcer. Oxford University Press, London.

Johnson D. H. (1955). The special significance of concomitant gastric and duodenal ulcers. Lancet, 1, 266-270.

James, A. H., and Pickering, G. W. (1949). The role of gastric acidity in the pathogenesis of peptic ulcer. Clin. Sci., 8, 181-210.

Konjetzny, G. E. (1928). Die Entzündung des Magens. In Handbuch der speziellen Pathologischen Anatomie und Histologie, edited by F. Henke and D. Lubarsch, Bd. IV, Th. 2. Springer, Berlin.

Landboe-Christiensen (1944). Extent of the pylorus zone in the human stomach. Acta path. microbiol. scand., suppl., 54, 671.

Magnus, H. A. (1946). The pathology of simple gastritis. J. Path. Bact., 58, 431-439.

(1952). Gastritis. In Modern Trends in Gastro-enterology, edited by F. A. Jones, pp. 323-351. Butterworth, London.

(1954). The pathology of peptic ulceration. Postgrad. med. J., 30, 131-136.

— and Rodgers H. W. (1938). The mucosa of the body of the stomach in chronic gastro-duodenal ulceration. St. Bart. Hosp. Rep., 71, 129-140.

Marks, I. N., and Drysdale, D. A. (1957). A modification of Zimmerman's method for differential staining of gastric mucosa. Stain Technol., 32, 48. 
Marks, I. N. and Shay, H. (1959). Observations on the pathogenesis of gastric ulcer. Lancet, 1, 1107-1111.

Meyers, W. C. (1948). A study of gastric mucosa in various diseases affecting the upper part of the gastro-intestinal tract. Gastroenterology, 10, 923-938.

Oi, M., Oshida, K., and Sugimura S. (1959). The location of gastric ulcer. Ibid., 36, 45-56.

Palmer, E. D. (1954). Gastritis: a revaluation. Medicine (Baltimore), $33,199-290$.

Papayannopoulos, G., Dedes, D., Kasralis, E., and Arealis, E. (1957). A study of antral gastritis in the resected stomachs. Gastroenterology, 32, 428-433.

Radasch, H. E. (1921). The distribution of acid cells of the stomach. Int. J. Gastroent. 1, 24-34.

Stewart, M. J. (1922). The healing of gastric ulcer. Brit. med. J., 2, 1164-1166. (1923a). The pathology of gastric ulcer. Ibid., 2,955-957, 1021-1025. (1923b). The morbid anatomy of gastric and duodenal ulcer. Int. Clin., ser. 33, 4, 1-13.

Tanner, N. C. (1954). Surgery of peptic ulceration and its complications. Postgrad. med. J., 30, 448-465.

Thompson, H. (1959). Gastritis in partial gastrectomy specimens. Gastroenterology, 36, 861-876.

Watkinson, G. (1960). The incidence of chronic peptic ulcer found at necroscopy. A study of 20,000 examinations performed in Leeds in 1930-49, and in England and Scotland in 1956. Gut, 1, 14-30.

_ and James, A. H. (1951). Twenty-four hour gastric analysis in patients with histamine achlorhydria. Clin. Sci., $10,255-266$.

Weisberg, H., and Glass, G. J. B. (1963). Coexisting gastric and duodenal ulcers: a review. Amer. J. dig. Dis., 8, 992-1007. 